\title{
NOWE PODEJŚCIE DO PROBLEMU PRZEMARZANIA GRUNTU W POLSCE
}

\author{
Tomasz Godlewski ${ }^{\bowtie}$ \\ Instytut Techniki Budowlanej, Warszawa
}

\begin{abstract}
STRESZCZENIE
Przemarzanie gruntu jest jednym ze zjawisk będących skutkiem oddziaływań klimatycznych - w tym przypadku ujemnej temperatury powietrza. Należy je brać pod uwagę w projektowaniu fundamentów budowli naziemnych, w projektowaniu obiektów liniowych (drogi) i urządzeń podziemnych. Głębokość, do której sięga przemarzanie gruntu, jest określana jako położenie izotermy zerowej. Ostatnia mapa stref przemarzania, podana w normie PN-81/B-03020, jest przeniesiona z poprzedniej normy z 1974 roku i bazuje na ograniczonych danych - pomiarach wykonanych podczas jednej, wyjątkowo mroźnej zimy 1962/63. Obecnie, dysponując wynikami pomiarów z około 30-50 lat, można do opracowania danych pomiarowych zastosować rachunek prawdopodobieństwa i oszacować prognozę głębokości położenia izotermy zerowej w gruncie, o akceptowanym prawdopodobieństwo przekroczenia $\mathrm{w}$ wybranym okresie odniesienia.

W referacie przedstawiono nowe podejście do problemu wyznaczania głębokości przemarzania, polegające na wykorzystaniu bezpośrednich danych pomiarowych temperatury gruntu, zgromadzonych przez stacje meteorologiczne IMiGW-PIB. Stosując rozkład prawdopodobieństwa Gumbela, wyznaczono głębokości położenia izotermy zerowej o okresie powrotu 50 lat. Uwzględniając warunki gruntowe na stacjach, sprowadzono otrzymane wyniki do warunków gruntu referencyjnego i zaproponowano nową mapę przemarzania gruntu.
\end{abstract}

Słowa kluczowe: zjawisko przemarzania gruntu, temperatura gruntu, czynniki wpływu, głębokość izotermy zerowej, mapa przemarzania gruntu

\section{WSTĘP}

Zjawisko przemarzanie gruntu to proces wielowymiarowy, niestacjonarny i losowo zmienny (Żurański i Godlewski, 2017). Jest jednocześnie współzależne od losowo zmiennych zjawisk klimatycznych oraz od częściowo stałych, a częściowo także losowo zmiennych (pod wpływem warunków zewnętrznych) właściwości gruntu. Losowo zmienne warunki zewnętrzne to podstawowe oddziaływania klimatyczne, takie jak: temperatura powietrza, opady i prędkość wiatru. Najważniejszym czynnikiem jest tu temperatura powietrza, a w przypadku przemarzania de facto czas trwania temperatury ujemnej. $\mathrm{W}$ takich warunkach wpływ na głębokość przemarzania mają zarówno opady śniegu tworzące pokrywę śnieżną, jak i prędkość wiatru, który wpływa na tę pokrywę. Znaczenie ma tu nie tylko sama grubość pokrywy śnieżnej, ale również jej właściwości i dalsza metamorfoza pod wpływem czynników zewnętrznych (temperatury powietrza, opadów i wiatru), które zmieniają gęstości śniegu, co wpływa na jego przewodność cieplną (Żurański i Sobolewski, 2016b). Intensywność zjawiska przemarzania jest też związana z opadami deszczu, zwłaszcza przed początkiem zamarzania gruntu, gdyż od nich zależy wilgotność gruntu.

Podejścia do ustalania normatywnej głębokości przemarzania gruntów można podzielić na empi-

$凶_{\text {t.godlewski@itb.pl }}$ 
ryczne i analityczne. Pierwsze opiera się na badaniach eksperymentalnych pola temperatury w gruncie i uogólnienie wyników w nawiązaniu do danych klimatycznych i klasyfikacji gruntów. Drugie polega na rozwiązaniu równania przewodnictwa cieplnego $\mathrm{w}$ gruncie $\mathrm{z}$ uwzględnieniem zmiany stanu skupienia wody w temperaturze $0^{\circ} \mathrm{C}$ lub niższej (Kozłowski, 1997). Na potrzeby opracowania nowej propozycji mapy przemarzania gruntu wykorzystano podejście empiryczne jako bardziej miarodajne do skali analizowanego zagadnienia (strefy o zasięgu regionalnym). Zasięg (głębokość) przemarzania gruntu jest zwykle utożsamiany $\mathrm{z}$ położeniem izotermy zerowej $\mathrm{w}$ gruncie. Oprócz czynników klimatycznych przemarzanie zależy oczywiście od samych właściwości gruntu, w tym m.in. od rodzaju, jego konsystencji, składu mineralnego czy zawartości wody. W związku z tym nie zawsze głębokość przemarzania jest taka sama jak położenie izotermy zerowej. Stacje meteorologiczne mierzą temperature gruntu i na tej podstawie wyznaczają położenie izotermy zerowej, dlatego w dalszych rozważaniach będzie ona uznawana za głębokość przemarzania (Żurański, Godlewski i Wereski, 2017).

\section{DOTYCHCZASOWE PODEJŚCIE DO OCENY PRZEMARZANIA GRUNTU W POLSCE}

Pierwsze wzmianki odnośnie przemarzania gruntu ukazały się w 1945 roku w normie dotyczącej gruntów budowlanych. Podano wtedy, że fundamenty zewnętrzne ścian budynków zwykłych powinny być zagłębione co najmniej: 1,0-1,2 $\mathrm{m}$ w województwach zachodnich, 1,2-1,6 $\mathrm{m}$ w środkowych, 1,5-2,0 m we wschodnich, w zależności od gruntu i ważności budynku. Kolejne ustalenia już w formie graficznej podano w normie PN-/B-03020 w wersji z lat 1955 i 1959 (ta sama mapa). Podano tam trzy strefy głębokości przemarzania: 0,$8 ; 1,0$ i $1,2 \mathrm{~m}$. W normie PN-74/B-03020 znalazła się dodatkowa strefa $1,4 \mathrm{~m}$ obejmująca północno-wschodni skrawek Polski, na wschód od Kętrzyna przez Ełk do granicy państwowej między Sokółką a Dąbrową Białostocką. W normie z 1981 roku wykorzystano tę samą mapę, lecz ze zmniejszoną liczbą naniesionych miejscowości w celu poprawy przejrzystości rysunku. Norma ta jest aktualna do dnia dzisiejszego. Użyte słowo „aktualna” jest tu nieprzy- padkowe, gdyż w zakresie aktualnych standardów dotyczących geotechniki (Eurokodu 7) nie pojawiło się nic nowego. W zapisach normy PN-EN 1997 nie ma nic odnośnie metodologii czy innych informacji odnośnie oceny przemarzania, poza stwierdzeniem, że należy przy projektowaniu fundamentów uwzględnić ich położenie (poniżej głębokości przemarzania).

Potrzeba uaktualnienia i uwiarygodnienia zaleceń normowych w zakresie przemarzania gruntu w Polsce była już podnoszona wielokrotnie. W publikacji z 1987 roku Ickiewicz i Pogorzelskiego wyrażono pogląd, że „krajowe dane doświadczalne o głębokości przemarzania gruntów wydają się niewystarczające, tak do utrzymania, jak i do zmiany wartości podanych w PN-81/B-03020, jeśli głębokość przemarzania ma być należycie uzasadniona, a nie oparta na ustaleniach arbitralnych. Brak jest bowiem systematycznych, wieloletnich pomiarów temperatury $\mathrm{w}$ gruncie, umożliwiajacych ustalenie obliczeniowych wartości głębokości przemarzania odpowiadających 50-letniemu czasowi powrotu". Podobnie krytycznie o dotychczasowych mapach przemarzania gruntu w Polsce wypowiadali się inni autorzy, np. Kozłowski (2003). Najnowsze dwie nowe propozycje ujęcia tego zagadnienia przedstawiono w pracach Gontaszewskiej (2010) oraz Ickiewicz (2010). Obie polegają na zastosowaniu tzw. współczynnika mrozowego, czyli liczby stopniodni ujemnej temperatury powietrza.

\section{MATERIAŁ I METODY}

Opisane powyżej propozycje nowych głębokości przemarzania można skonfrontować $\mathrm{z}$ wynikami analizy rzeczywistej temperatury gruntu, na którą, jak już wspomniano, wpływa więcej czynników niż tylko temperatura. W tym celu wykorzystano dane z bezpośrednich pomiarów na stacjach meteorologicznych IMiGW-PIB. Wyniki tych pomiarów zostały wykorzystane w opracowaniu nowej propozycji mapy przemarzania gruntu. Sposób prowadzenia pomiarów i metodykę wyznaczania położenia izotermy zerowej $\mathrm{w}$ gruncie podano w instrukcji (Janiszewski, 1988). Po dokonaniu pomiarów, obserwator na stacji meteorologicznej wyznacza następnie położenie izotermy zerowej. W przypadku, gdy położenie izotermy zerowej znajduje się poniżej 1,0 m (maksymalna głębokość 
pomiarowa), aby uzyskać jej położenie dokonuje się ekstrapolacji wyników pomiarów z głębokości 1,0 m i płyciej. Szczegółowe informacje są podane w publikacji Żurańskiego i Sobolewskiego (2016a).

Podobnie jak w przypadku innych oddziaływań klimatycznych (Żurański i Sobolewski, 2016b) do prognozowania wartości położenia izotermy zerowej w gruncie dobrze nadaje się rozkład prawdopodobieństwa Gumbela (1958). Prognozowane wartości oblicza się, aproksymując tym rozkładem prawdopodobieństwa rozkłady empiryczne wartości maksymalnych rocznych (zimowych). Na podstawie wykonanych analiz dla ustalonego położenie izotery zerowej w warunkach gruntowych dla 45 stacji meteorologicznych (wykorzystując dane z ostatnich 30-32 lat obserwacji), stosując opisany rozkład Gumbela, uzyskano rozkład terytorialny wartości prognozowanych położenia izotermy zerowej w gruncie. Przyjęto, że tak jak w przypadku oddziaływań klimatycznych (Żurański i Sobolewski, 2016b) wartości charakterystyczne położenia izotermy zerowej powinny mieć okres powrotu 50 lat.

Na głębokość przemarzania mają wpływ czynniki związane z podłożem gruntowym, takie jak: rodzaj gruntu, jego stan, stopień nasycenia, porowatość i skład mineralny oraz układ warstw. Przed przystapieniem do przeliczania otrzymanych wyników z uwzględnieniem cech gruntu, należało ustalić warunki w podłożu analizowanych stacji meteorologicznych, czyli ustalić profil, w którym były wykonywane pomiary temperatury. W tym celu dokonano znormalizowania uzyskanych wyników, odnosząc je do warunków tzw. gruntu odniesienia (referencyjnego). Przyjmując głębokość położenia izotermy zerowej jak dla piasków grubych i średnich (także w żwirze), jako podstawową można dla innych rodzajów gruntu wprowadzić współczynniki wynikające ze stosunku podanych wartości do wartości maksymalnej. Wykorzystano tu podział podanych w dotychczasowych pracach, np. według wytycznych NiTU (127-55), Gontaszewska (2010). Wskazano na cztery podstawowe rodzaje (litotypy), przypisując im następujące współczynniki: żwiry, piaski grube i średnie $-1,00$; piaski drobne i pylaste $-0,90$; pyły i gliny piaszczyste $-0,80$; iły i inne gliny $-0,70$. Można przyjąc (z braku innych danych), że przyjęte wartości współczynników oddają stosunki położenia izotermy zerowej między wymienionymi rodzajami gruntu (Żurański i Godlewski, 2017). W przypadku 31 stacji meteorologicznych warunki gruntowe ustalono na podstawie informacji zawartych w opisach profili glebowych stacji IMGW-PIB. Pozostałe 14 stacji nie miały takich opisów, w tych przypadkach warunki gruntowe ustalono na podstawie wydzieleń opisanych według dostępnych danych geologicznych $(\mathrm{SmgP}$ w skali $1: 50000)$.

\section{WYNIKI I DYSKUSJA}

Uzyskane wyniki analizy probabilistycznej danych pomiarowych skorygowano według wartości współczynnika poprawkowego z uwagi na rodzaj gruntu, odnosząc je do jednolitych warunków gruntowych, za które przyjęto żwiry, piaski grube i średnie. Wyniki obliczeń, po znormalizowaniu warunków gruntowych i przeprowadzeniu podziału na strefy (na podstawie analizy parametrów statystycznych), podano $\mathrm{w}$ tabeli 1 .

Na podstawie wszystkich wyników wykreślono dwie mapy, jedną metodą spline (funkcji sklejanej) (rys. 1), a drugą metodą krigingu (uogólnionej regresji) (rys. 2). Obie mapy robocze obrazują położenie izotermy zerowej w gruncie o okresie powrotu 50 lat. Położenie to ustalono na podstawie wyników analizy danych z 45 stacji meteorologicznych. Mapy opracowano na podstawie danych uzyskanych z szacowania parametrów rozkładu prawdopodobieństwa metodą najmniejszych kwadratów (MNK), a w przypadku kilku stacji (Koło, Nowy Sącz, Piła, Rzeszów i Zakopane) metodą największej wiarygodności (MNW).

Po analizach wybrano mapę wykreśloną metoda krigingu, która lepiej przedstawia przebieg izolinii w sytuacji ograniczonej ilości danych i nierównomiernego charakter lokalizacji stacji pomiarowych (rys. 3). Dla lepszej przejrzystości mapy na podstawie wyników analizy statystycznej (kryterium było tu m.in. zmienność głębokości w obrębie wyznaczonej strefy na poziomie $+/-0,10 \mathrm{~m}$ ) wskazano na możliwość utworzenia czterech głównych stref przemarzania, trzech o wartościach zbliżonych do tych $\mathrm{z}$ dotychczas stosowanej normy oraz strefy górskiej o wartości zależnej od wysokości nad poziomem morza $(A)$, lecz nie mniejszej niż 1,0 m (tab. 2). 
Godlewski, T. (2018). Nowe podejście do problemu przemarzania gruntu w Polsce. Acta Sci. Pol. Architectura, 17 (3), 121-129. doi: 10.22630/ASPA.2018.17.3.34

Tabela 1. Wyniki obliczeń znormalizowanych ze względu na rodzaj gruntu

Table 1. Calculation results standardized for soil category

\begin{tabular}{|c|c|c|c|c|c|}
\hline \multirow{2}{*}{$\begin{array}{l}\text { Stacja } \\
\text { Station }\end{array}$} & \multirow{2}{*}{$\begin{array}{c}\text { Współczynnik } \\
\text { przeliczeniowy } \\
\text { Coefficient of } \\
\text { standardization }\end{array}$} & \multicolumn{2}{|c|}{$\begin{array}{l}\text { Wyniki bez korekty } \\
\text { Results without correction }\end{array}$} & \multicolumn{2}{|c|}{$\begin{array}{l}\text { Wyniki skorygowane } \\
\text { Standardized results }\end{array}$} \\
\hline & & $\begin{array}{l}z_{50}[\mathrm{~m}] \\
\mathrm{MNK}\end{array}$ & $\begin{array}{l}z_{50}[\mathrm{~m}] \\
\mathrm{MNW}\end{array}$ & $\begin{array}{l}z_{50, \text { kor }} \\
\text { MNK }\end{array}$ & $\begin{array}{l}z_{50 \text {, kor }} \\
\text { MNW }\end{array}$ \\
\hline Białystok & 0,9 & 1,188 & 1,072 & 1,32 & 1,19 \\
\hline Bielsko-Biała & 0,7 & 0,648 & 0,586 & 0,93 & 0,84 \\
\hline Chojnice & 0,8 & 1,275 & 1,139 & 1,59 & 1,42 \\
\hline Elbląg & 0,8 & 1,024 & 0,993 & 1,28 & 1,24 \\
\hline Gorzów Wlkp. & & 1,135 & - & 1,42 & - \\
\hline Hala Gąsienicowa & 1,0 & 0,935 & - & 0,94 & - \\
\hline Jelenia Góra & 1,0 & 0,989 & 0,986 & 0,99 & 0,99 \\
\hline Kalisz & 0,8 & 1,149 & 1,124 & 1,44 & 1,41 \\
\hline Katowice & 0,9 & 0,736 & 0,649 & 0,82 & 0,72 \\
\hline Kętrzyn & 0,7 & 0,952 & 0,929 & 1,36 & 1,33 \\
\hline Kielce & 1,0 & 1,239 & 1,133 & 1,24 & 1,13 \\
\hline Kłodzko & 0,8 & 0,878 & 0,848 & 1,10 & 1,06 \\
\hline Koło & 0,7 & 0,989 & 1,006 & 1,41 & 1,44 \\
\hline Koszalin & 0,7 & 0,956 & 0,901 & 1,37 & 1,29 \\
\hline Kozienice & 1,0 & 1,391 & - & 1,39 & - \\
\hline Kraków-Balice & 0,9 & 0,846 & 0,839 & 0,94 & 0,93 \\
\hline Legnica & 0,9 & 1,177 & 1,115 & 1,31 & 1,24 \\
\hline Lesko & 0,9 & 0,789 & 0,720 & 0,88 & 0,80 \\
\hline Leszno & 0,8 & 1,099 & 1,064 & 1,37 & 1,33 \\
\hline Lublin & 0,8 & 1,020 & 0,960 & 1,28 & 1,20 \\
\hline Łeba & 0,9 & 0,825 & 0,855 & 0,92 & 0,95 \\
\hline Łódź & 0,9 & 1,216 & 1,181 & 1,35 & 1,31 \\
\hline Mikołajki & 0,7 & 0,959 & 0,898 & 1,37 & 1,28 \\
\hline Mława & 0,8 & 1,153 & 1,029 & 1,44 & 1,29 \\
\hline Nowy Sącz & 0,9 & 0,643 & 0,643 & 0,71 & 0,71 \\
\hline Opole & 1,0 & 1,103 & 1,013 & 1,10 & 1,01 \\
\hline Piła & 1,0 & 1,269 & 1,288 & 1,27 & 1,29 \\
\hline Płock & 1,0 & 1,027 & 0,919 & 1,03 & 0,92 \\
\hline Poznań & 0,8 & 1,333 & 1,308 & 1,67 & 1,64 \\
\hline Resko & 1,0 & 0,908 & 0,836 & 0,91 & 0,84 \\
\hline Rzeszów & 1,0 & 0,802 & 0,863 & 0,80 & 0,86 \\
\hline Sandomierz & 0,9 & 1,136 & 1,076 & 1,26 & 1,20 \\
\hline
\end{tabular}


Godlewski, T. (2018). Nowe podejście do problemu przemarzania gruntu w Polsce. Acta Sci. Pol. Architectura, 17 (3), 121-129. doi: 10.22630/ASPA.2018.17.3.34

\begin{tabular}{|c|c|c|c|c|c|}
\hline \multirow{2}{*}{$\begin{array}{l}\text { Stacja } \\
\text { Station }\end{array}$} & \multirow{2}{*}{$\begin{array}{l}\text { Współczynnik } \\
\text { przeliczeniowy } \\
\text { Coefficient of } \\
\text { standardization }\end{array}$} & \multicolumn{2}{|c|}{$\begin{array}{l}\text { Wyniki bez korekty } \\
\text { Results without correction }\end{array}$} & \multicolumn{2}{|c|}{$\begin{array}{l}\text { Wyniki skorygowane } \\
\text { Standardized results }\end{array}$} \\
\hline & & $\begin{array}{l}z_{50}[\mathrm{~m}] \\
\mathrm{MNK}\end{array}$ & $\begin{array}{l}z_{50}[\mathrm{~m}] \\
\mathrm{MNW}\end{array}$ & $\begin{array}{l}z_{50, \text { kor }} \\
\text { MNK }\end{array}$ & $\begin{array}{l}z_{50 \text {,kor }} \\
\text { MNW }\end{array}$ \\
\hline Siedlce & 1,0 & 1,056 & - & 1,06 & - \\
\hline Stubice & 1,0 & 0,964 & 0,903 & 0,96 & 0,90 \\
\hline Suwałki & 0,8 & 1,064 & 1,056 & 1,33 & 1,32 \\
\hline Szczecin & 1,0 & 1,199 & 1,124 & 1,20 & 1,12 \\
\hline Świnoujście & 1,0 & 1,179 & 1,165 & 1,18 & 1,17 \\
\hline Tarnów & 1,0 & 0,952 & 0,922 & 0,95 & 0,92 \\
\hline Terespol & 1,0 & 0,926 & 0,903 & 0,93 & 0,90 \\
\hline Toruń & 1,0 & 1,308 & 1,216 & 1,31 & 1,22 \\
\hline Warszawa & 0,9 & 1,053 & 1,044 & 1,17 & 1,16 \\
\hline Wieluń & 0,8 & 1,107 & 1,018 & 1,38 & 1,27 \\
\hline Włodawa & 0,9 & 1,481 & 1,387 & 1,65 & 1,54 \\
\hline Zakopane & 1,0 & 1,094 & 1,145 & 1,09 & 1,15 \\
\hline Zielona Góra & 1,0 & 1,690 & 1,503 & 1,69 & 1,50 \\
\hline
\end{tabular}

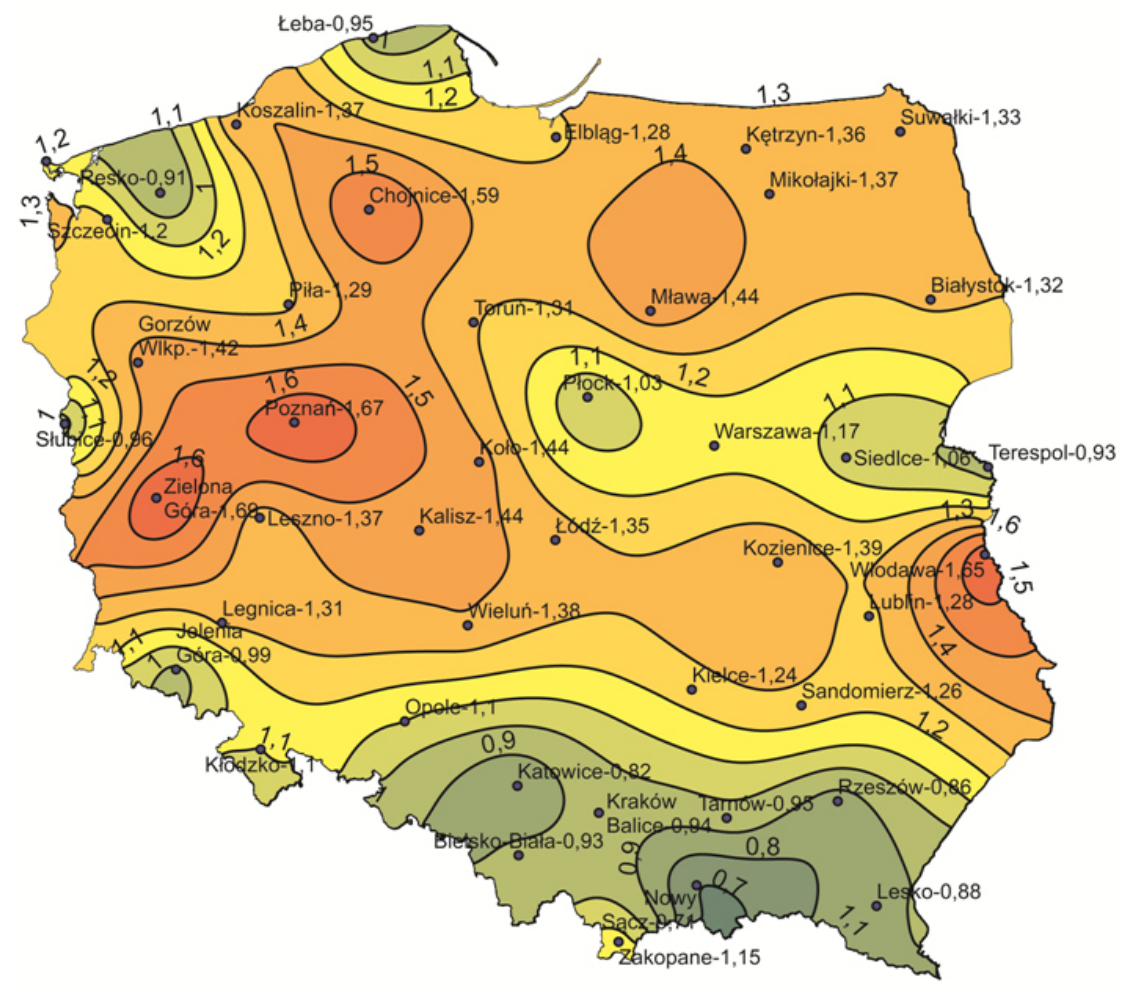

Rys. 1. Wersja robocza mapy położenia izotermy zerowej - metodą spline (Żurański i Godlewski, 2017)

Fig. 1. Draft of a zero isotherm location map - spline method (Żurański \& Godlewski, 2017) 


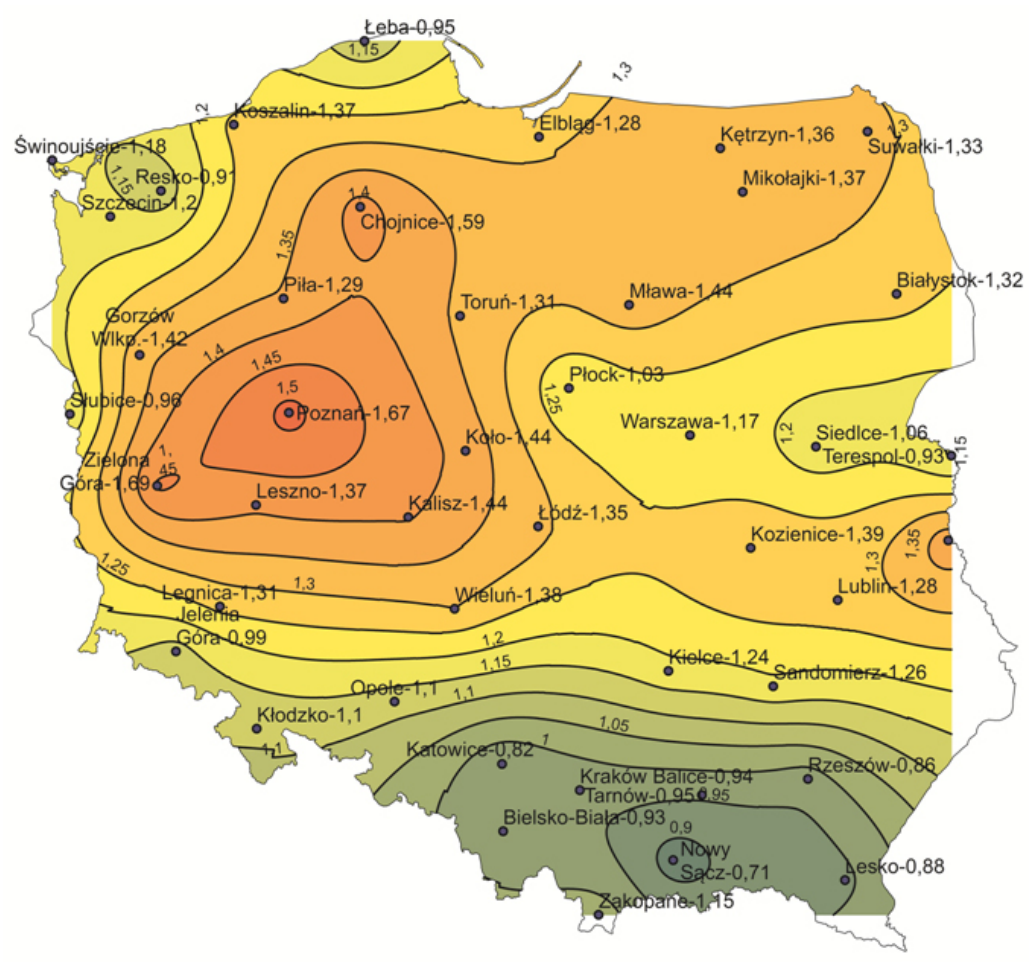

Rys. 2. Wersja robocza mapy położenia izotermy zerowej - metodą krigingu (Żurański i Godlewski, 2017)

Fig. 2. Draft of a zero isotherm location map - kriging method (Żurański \& Godlewski, 2017)

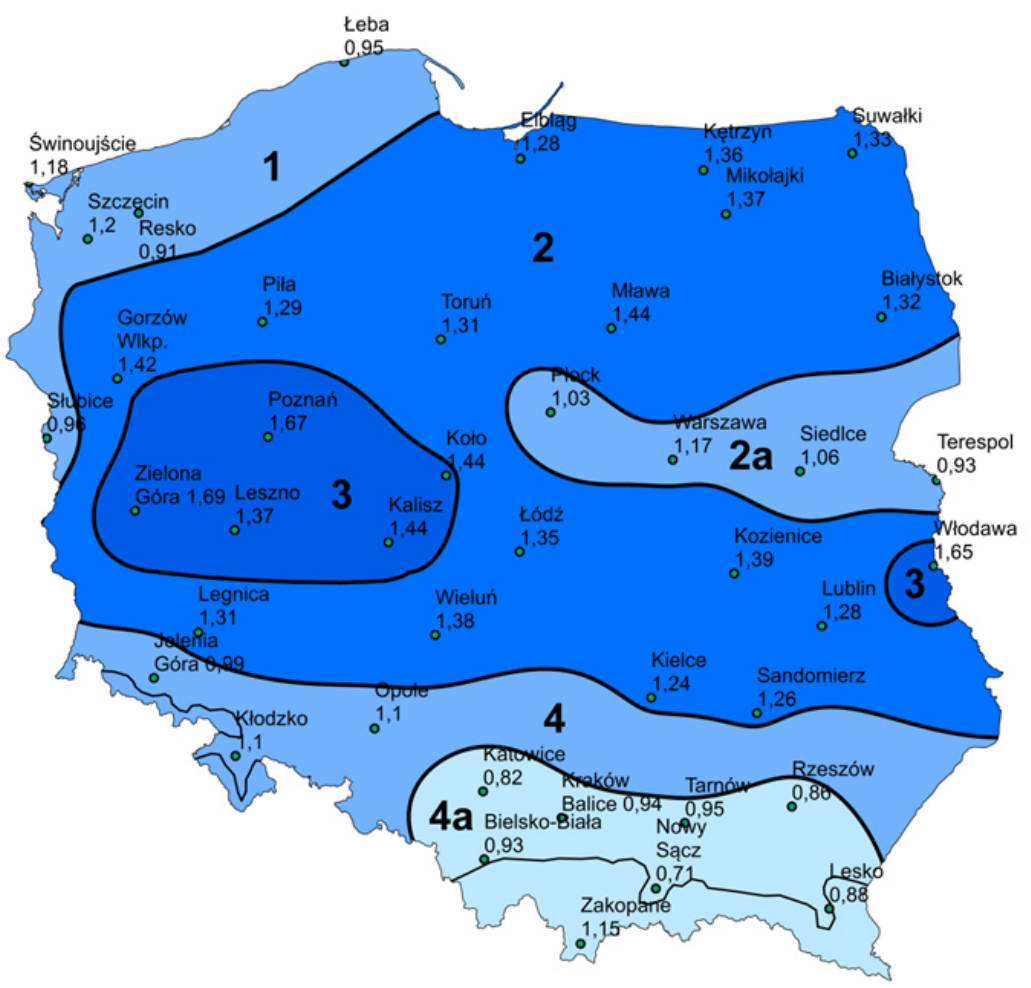

Rys. 3. Propozycja nowej mapy przemarzania gruntu w Polsce (Żurański i Godlewski, 2017)

Fig. 3. Proposal for a new map of soil freezing depth in Poland (Żurański \& Godlewski, 2017) 
Tabela 2. Wstępne wartości strefowe głębokości położenia izotermy zerowej w Polsce (Żurański i Godlewski, 2017)

Table 2. Intended zonal values of soil freezing depth in Poland (Żurański \& Godlewski, 2017)

\begin{tabular}{cc}
\hline $\begin{array}{c}\text { Strefa } \\
\text { Zone }\end{array}$ & $\begin{array}{c}\text { Głębokość położenia izotermy zerowej, } Z k[\mathrm{~m}] \\
\text { Soil freezing depth, } Z k[\mathrm{~m}]\end{array}$ \\
\hline 1 & 1,1 \\
\hline 2 & 1,3 \\
\hline $2 \mathrm{a}$ & 1,1 \\
\hline 3 & 1,5 \\
\hline 4 & $0,6+0,0007 \cdot A ; Z_{k} \geq 1,1 \mathrm{~m}$ \\
\hline $4 \mathrm{a}$ & $0,6+0,0007 \cdot A ; Z_{k} \geq 1,0 \mathrm{~m}$ \\
\hline
\end{tabular}

$A$ - wysokość [m n.p.m.].

Proponowana strefa 1, o wartości strefowej $Z_{k}=1,1 \mathrm{~m}$, byłaby położona na terenach bliskich wybrzeża Morza Bałtyckiego. Strefa 2 o wartości strefowej $Z_{k}=1,3$ m obejmowałaby większość terytorium Polski, z wyłączeniam trójkąta Wieluń-Zielona Góra-Chojnice-Wieluń, wewnątrz którego byłaby wartość 1,5 m. Na południu Polski byłyby strefy podgórska i górska o wartościach zależnych od wysokości nad poziomem morza, lecz nie mniejszyh niż 1,0 m. Jej granica północna przebiegałaby w przybliżeniu od Przemyśla do Opola i Jeleniej Góry (Żurański i Godlewski, 2017).

\section{PODSUMOWANIE}

Uzyskane wyniki świadczą o tym, że można (na podstawie obserwacji i bezpośrednich pomiarów $\mathrm{z}$ ponad 30 lat) i należy zmienić dotychczasową mapę, która była opracowana na podstawie obliczeń za pomoca przybliżonych wzorów uwzględniających jedynie temperature powietrza. Probabilistyczna analiza temperatury gruntu uwzględnia losowy charakter zjawiska i udział w nim nie tylko temperatury powietrza, lecz także pokrywy śnieżnej i zawartości wody w gruncie wynikającej z wcześniejszych opadów deszczu, przed wystąpieniem mrozu.

W zakresie opisanych czynników można wskazać prace podejmowane w ITB (Piaskowski, 1993), dotyczące oceny wpływu rodzaju gruntu (glina, glina zwięzła, kaolin) i jego wilgotności (stanu) na wartość temperatury początku zamarzania. Przy bardzo małej wilgotności $(<10 \%)$ badany grunt zamarzał $\mathrm{w}$ temperaturze niższej niż $0^{\circ} \mathrm{C}$, nawet poniżej $-3^{\circ} \mathrm{C}$. Bardziej aktualne rozważania na temat zmian temperaturowych i zjawiskach $\mathrm{z}$ tym związanych w gruntach można znaleźć w pracy Kozłowskiego (1997). W pracach tych wykazano, że grunt suchy przemarza głębiej. Warto w tym miejscu zauważyć, że strefa najgłębszego przemarzania pokazana na nowej propozycji mapy przemarzania gruntów (rys. 3) pokrywa się w dużym stopniu z obszarem najmniejszej średniej grubości pokrywy śnieżnej oraz najmniejszych opadów deszczu w porze ciepłej, czyli najmniejszej wilgotności gruntu (mapy wg danych IMGiW, przedstawione w pracy z 2017 r. Żurańskiego i Godlewskiego). Ważną informacją byłyby tu dane o wilgotności gruntu na obszarze Polski. Takich danych jednak brak. Wilgotność gruntu zależy od wielkości opadów, a te są mierzone tylko przez stacje meteorologiczne. Mapy średnich, wieloletnich sum opadów mogą być orientacyjnym wskaźnikiem wilgotności gruntu do wykorzystania w dalszych pracach.

W tym kontekście należy zauważyć, że zastosowanie do obliczeń położenia izotermy zerowej wskaźnika mrozowego może prowadzić do niedoszacowań. W metodzie tej nie uwzględnia się pokrywy śnieżnej, co ma istotne znaczenie, ponieważ wówczas głębokości przemarzania gruntu są większe, niekiedy znacznie. Metoda wyznaczania głębokości przemarzania gruntu za pomocą wskaźnika mrozowego (liczby stopniodni) jest szeroko stosowana w krajach, w których wystę- 
puje ujemna temperatura powietrza i długo utrzymuje się pokrywa śnieżna (np. kraje Skandynawii, Kanada). Wynika to zapewne $\mathrm{z}$ braku pomiarów temperatury gruntu, a także z przywiązania do metod tradycyjnych, opracowanych w czasie, gdy temperatury gruntu nie mierzono, a pomiary temperatury powietrza należały i należą do podstawowych pomiarów prowadzonych przez sieć stacji meteorologicznych.

Opisany grunt referencyjny bierze pod uwagę jedynie jego rodzaj (litologię). Jest to duże uproszczenie, ale na obecnym etapie nie było możliwe (brak takich danych) uwzględnienie dodatkowych czynników, które mają wpływ na głębokość przemarzania, takich jak: stan gruntu, stopień nasycenia, porowatość i skład granulometryczny. Kolejne czynniki, które lokalnie moga mieć istotny wpływ na rzeczywista głębokość przemarzania, to aktualne położenie zwierciadła wód gruntowych i jej chemizm, sytuacja morfologiczna - możliwość lokalnych anomalii np. w kotlinach czy na wzniesieniach oraz uwarunkowania związane z ekspozycja terenu - stoki południowe, obecność i rodzaj szaty roślinnej czy charakter zagospodarowania. Proponowaną klasyfikację gruntów, jak również sposób jej uwzględnienia w obliczeniach głębokości przemarzania należy uznać jako podejście wstępne.

Wskazane jest prowadzenie badań doświadczalnych, których bardzo ważnym celem jest uściślenie zależności położenia izotermy zerowej od rodzaju gruntu, zależności między położeniem izotermy zerowej a rzeczywistą głębokością przemarzania. Aktualnie prowadzone są już prace $\mathrm{w}$ tym kierunku, np. w zakresie wpływu niskiej temperatury na parametry mechaniczne różnych typów gruntów (temat badawczy w ITB NZK-069 na lata 2016/2019 przez W. Bogusza i M. Witowskiego).

Prezentowany artykuł ma na celu zasygnalizowanie problemu, wskazując na wyniki pracy otwierającej nowy rozdział dotyczący oceny głębokości przemarzania gruntów z nowatorskim wykorzystaniem wyników pomiarów bezpośrenich temperatury gruntu do prognozowania głębokości jego przemarzania. Więcej szczegółów na ten temat można znaleźć w monografii z 2017 roku J.A. Żurańskiego i T. Godlewskiego „O przemarzaniu gruntu w Polsce”. Artykuł stanowi uzupełnienie i rozwinięcie opisywanych zagadnień, które były już sygnalizowane na 63. konferencji naukowej KILiW PAN oraz KN PZITB w Krynicy Zdrój w 2017 roku jako efekt zakończenia prac i ukazania się wymienionej wcześniej monografii.

\section{ADNOTACJA}

W referacie wykorzystano wyniki pracy wykonanej w ramach tematu statutowego Instytutu Techniki Budowlanej NZK-37 „Wybrane oddziaływania klimatyczne na obiekty budowlane" finansowanego przez Ministerstwo Nauki i Szkolnictwa Wyższego.

\section{DEDYKACJA}

Pamięci prof. J. A. Żurańskiego.

\section{PIŚMIENNICTWO}

Gontaszewska, A. (2010). Własności termofizyczne gruntów w aspekcie przemarzania. Zielona Góra: Uniwersytet Zielonogórski.

Gumbel, E.J. (1958). Statistics of extremes. New York: Columbia University Press.

Ickiewicz, I. (2010). Posadowienie fundamentów bezpośrednich w funkcji przemarzania gruntów. Rozprawy Naukowe 202. Oficyna Wydawnicza Politechniki Białostockiej.

Ickiewicz, I. i Pogorzelski, J.A. (1987). Wpływ wybranych czynników na głębokość przemarzania gruntów. Inżynieria i Budownictwo, 1 (12), 338-342.

Janiszewski, F. (1988). Instrukcja dla stacji meteorologicznych. Warszawa: IMiGW. Wydawnictwa Geologiczne.

Kozłowski, T. (1997). Skład fazowy wody w gruntach spoistych poniżej $0^{\circ}$ C. Monografie Studia Rozprawy 6. Kielce: Wydawnictwo Politechniki Świętokrzyskiej.

Kozłowski, T. (2003). Głębokość przemarzania krajowych gruntów budowlanych w aspekcie PN-81/B-03020 i projektu jej zmian. Inżynieria $i$ Budownictwo, 3, $168-170$.

NiTU 127-55. Normam i tiechniczeskim usłowijam projektirowanija jestiestwiennychosnowanij zdanij i promysztennych soorużenij.

PN-EN 1997-2:2009. Eurokod 7 - Projektowanie geotechniczne. Część 2: Rozpoznanie i badanie podłoża gruntowego.

PN-EN 1997-1. Eurokod 7 - Projektowanie geotechniczne. - Część 1: Zasady ogólne. 
PN-EN 1997-2: 2009. Eurokod 7 - Projektowanie geotechniczne. Część 2: Badania podłoża gruntowego.

Piaskowski, A.M. (1993). Badania nad temperaturą zamarzania gruntów. W X Krajowa Konferencja Mechaniki Gruntów i Fundamentowania, Warszawa (strony 149-154).

Żurański, J.A. i Godlewski, T. (2017). O przemarzaniu gruntu w Polsce. Prace Naukowe, Monografie. Warszawa: Instytut Techniki Budowlanej.

Żurański, J.A., Godlewski, T. i Wereski, S. (2017). O pracach nad nową mapą przemarzania gruntu w Polsce. Acta
Scientiarum Polonorum, Architektura, 16 (3), 59-68.

Żurański, J.A. i Sobolewski A. (2016a). Probabilistic Approach to the Assessment of the Depth of Soil Freezing. W Proceedings of 13th Baltic Sea Region Geotechnical Conference, Vilnius, (strony 104-107). Vilno: Vilnius Gediminas Technical University (VGTU) Press.

Żurański, J.A. i Sobolewski, A. (2016b). Obciążenie śniegiem w Polsce w projektowaniu i diagnostyce konstrukcji. Prace Naukowe, Monografie. Warszawa: Instytut Techniki Budowlanej.

\title{
NEW APPROACH TO THE PROBLEM OF SOIL FREEZING IN POLAND
}

\begin{abstract}
In the paper present state of the codification of soil freezing depth in Poland is presented as well as last proposals of changes. Two of them are based on the use of so called air freezing index that is a method of degreedays. New approach presented in the paper is based on the results of measurements of soil temperature carried out by meteorological stations belonging to the Institute for Meteorology and Water Management - State Research Institute. Annual (winter) maxima of the position of the zero centigrade temperature measured in the soil were approximated by Gumbel probability distribution of extremes and characteristic values of 50 year return period have been calculated. The soil structures at the meteorological stations were taken into consideration and correction coefficients have been proposed. Proposal of a new map of soil freezing depth in Poland is presented for the soil assumed as a reference one.
\end{abstract}

Key words: phenomenon of soil freezing, soil temperature, impact factors, depth zero centigrade isotherm, map of soil freezing 